\title{
Daniela TEODORESCU
}

I

am pleased to present our 2004 issue of Chimères. Our articles this year are on very diverse topics and cover nearly every period of French and Francophone literature. There are nevertheless some echoes between the studies.

A number of our writers showed an interest in "dialogue": the dialogue of the arts, or of genres, of writers, of writers and critics, of storytellers and their audience. I begin this part of our issue with Selbee Diouf's Interview with Senegalese writer Aminata Sow Fall (a recipient of the Goncourt Prize), in which Sow Fall speaks of her attitude towards feminism in writing. Our second selection is Catharine Randall's study of different voices in Ronsard's poetry through the musical notions of polyphony and counterpoint. Carla Calargé's study brings together the world of the typically French bande dessinée through "Asterix," and of the Francophone novel and the life of beurs through Le Gone du Chaâba by Azouz Begag. Christy Wampole explores the Foucauldian concept of writers creating potential works actualized by their followers. Sandrine Teixidor studies the powers of storytellers in their society and over their audience as well as their representation of the collective mind of their community.

Our other writers explored questions of identity for men and women in different historical and social contexts, often as a function of violence. Kirsten Halling looks at identity in relation to power as it manifests itself through cultural and symbolic capital and social interactions. Ann Kontor discovers a medieval story about the Saracene Saladin that unlike other epics portrays him as a courtly hero resembling his Christian counterparts. Babacar Ndiaye looks at particularly masculine traits as he examines the definition of the male hero in Les gardiens du temple by Cheikh Hamidou. And finally, Bérénice Le Marchand studies the Aristotelian definition of the woman hero in Racine's theatre as it is embodied and subverted.

In this issue $I$ have decided also to include small biographies of the authors, in order to show the variety of backgrounds of our writers. Chimères is a graduate journal run entirely by graduate students, with advice from faculty in the French Department at the University of Kansas. 
Most of the articles we receive are from graduate students who are about to finish their doctorate. However, we have accepted good articles from Master students. We have also published articles from professors, some of them in the beginning stages of their career, and others well-known. Our journal has gained visibility with time, and major libraries in France, Germany, Italy and the US are currently subscribed to it.

The process of choosing articles and preparing them for publication involves quite a bit of serious work, but is also very stimulating. This year, the members of the Editorial board met several times a semester to discuss articles that we had received. We were able thus to put together a list of suggestions for the authors. These meetings were enjoyable, sometimes involving tea and cookies, and other times leading to unexpectedly heated debates. The second stage, preparing accepted work for publication, involved checking every rule in the book (the MLA style manual) to make sure the format of each article complied. This is detail work, but aspect matters as much as content. To everyone who has helped make this year's issue of Chimères possible, Selbee Diouf, Frédérique Sevet, Anna Lambertson, Regina Peszat, Mohammad Mohtashemipour, Professor Caroline Jewers and Ms. Pam LeRow from the CLA\&S Word Processing Center, I would like to say Thank You.

University of Kansas 